INDICATIVE ECONOMIC PLANNING WITH A

SIXTEEN SECTOR PROJECTION MODEL

OF THE NEW ZEALAND ECONOMY

B.I. Ross

\&

B. P. Philpott

A Paper presented to 41 st Congress of A.N.Z.A.A.S. Adelaide, 1969

Agricultural Economics Research Unit Discussion Paper No. 12

Lincoln College, University of Canterbury, N.Z.

August 1969 




\section{INDICATIVE ECONOMIC PLANNING WITH A SIXTEEN SECTOR PROJECTION MODEL OF THE NEW ZEALAND ECONOMY}

\section{INTRODUCTION}

The main purpose of this paper is to describe the exercise in ir ticative economic planning which has been carried out in New Zealand over the last 18 months. After outlining the background to the National Development Conference, a description is given of the sectoral projection model used for the Conference and the process of reconciliation carried on between estimates by individual sector committees and the estimates derived from the overall model. Some comparisons of different estimates are given, and some of the deficiencies of the present model are briefly discussed.

Major economic or political initiatives in New Zealand, as elsewhere, tend to be conceived in times of adversity. The spate of new social legislation in the 1890's followed a long depression, and the depression of the early 1930's led to an eager acceptance of the far-reaching measures introduced by the Labour Government elected late in 1935.

Smaller needs have also produced their equivalent responses. The housing shortage of the early 1950's resulted in a National Housing Conference in 1953, at which targets were set representing a 25 per cent increase in the building rate. These targets were successfully achieved.

Concern over the slackening rate of agricultural progress at the beginning of the present decade led to the calling of an Agricultural Development Conference in 1963. 
Targets for output and exports were set, and after a rather slow start, these targets have been more or less met to date in volume terms. Export earnings, however, are just ds dependant on prices as on volumes, and the prices received for New Zealand's agricultural exports over the last few years have been disappointing. Overseas earnings in 1965/66 and 1966/67 were quite inadequate to sustain the high levels of imports and the overseas payments recorded in those years, and the current account deficit grew alarmingly.

\section{Table I}

\section{Overseas Exchange Transactions} Years ended $31 \mathrm{March}$

$\$ m n$.

Receipts:

Exports

Total Current Receipts

Official Capital

I. M.F. Drawing

Private Capital

Total Capital

Receipts

Total Receipts

1964

1965

1966

1967

$\underline{1968}$

1969

$\begin{array}{llllll}730.4 & 768.6 & 774.1 & 795.8 & 787.8 & 953.8\end{array}$

$\begin{array}{llllll}800.2 & 846.9 & 858.4 & 887.9 & 890.6 & 1095.8\end{array}$

40.8

$22.8 \quad 106.6$

182.

148.5

95.0

20.6

50.3

$-$

66.8

$-$

61.4

30.3

22.7

24. 0

53.1

43.0

$53.1 \quad 179.6$

206.2

268. 4

138.0

$\begin{array}{llllll}861.6 & 900.0 & 1038.0 & 1094.2 & 1159.0 & 1233.8\end{array}$

Payments:

Imports

Other Curreat Payments

Total Current Payments

Official Capital

Private Capital

Total Capital

627.6

$656.9 \quad 742.4$

722.3

631.8

744.6

188.

$214.3 \quad 233.6$

272.2

276.2

306.2

816.0

$871.3 \quad 97 \dot{6} .0$

994.6

908.0

1050.9

Total Payments

43.2

15.6

84.3

69.

153.6

165.8

13.2

25.3

25. 0

25.2

29.7

39.1

56.4

$41.0 \quad 109.2$

94.5

183.3

204.9

872.4

912.31085 .2

$1089.0 \quad 1091.3$

1255.8

Balance on Current

$-15.8$

$-24.4-117.5$

$-106.6-17.4$

$+44.9$

Transactions

Balance on Capital

$+5.0$

$+12.1$

$+70.4$

$+111.8+85.1$

$-66.9$

Source: Economic Reviews 
The manageable current account deficits recorded in the overseas exchange transactions for the years ended March 31 st 1964 and 1965 grew to over $\$ 100 \mathrm{mn}$. for the 1966 and 1967 March years, equivalent to over 10 per cent of total current payments in each year.

Strong measures to deal with this situation were imposed by the Government in the first half of 1967, and aided by devaluation in November of that year, they produced a rapid improvement in the balance of overseas exchange transactions. The current account deficit for the year ended March 1968 was less than $\$ 18 \mathrm{mn}$, and for the year ended March this year, even this small deficit had been improved upon with a worthwhile surplus of nearly $\$ 45 \mathrm{mn}$.

This dramatic recovery in the external situation was only achieved at the expense of internal growth, and as Tables II and III demonstrate, the cost was quite high. 
4.

Table II

Gross Domestic Product and Expenditure

\section{Gross Domestic \\ Product at \\ Current Prices}

$\$ m n$.

$1957 / 58$
$1958 / 59$
$1959 / 60$
$1960 / 61$
$1961 / 62$
$1962 / 63$
$1963 / 64$
$1964 / 65$
$1965 / 66$
$1966 / 67$
$1967 / 68$

Source :

\author{
Gross Domestic \\ Product at \\ 1954/55 Prices
}

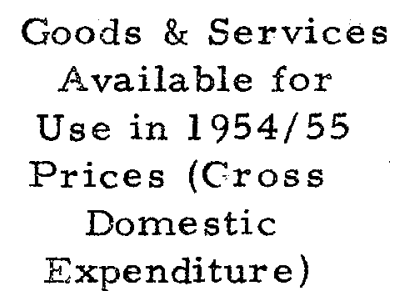

2087

2145

2230

2367

2446

2521

2675

2838

3011

3135

3103
2102
2031
2086
2359
2394
2418
2633
2842
3105
3201
3005

Cross Domestic Product in Constant Prices 1954/55 to $1967 / 68$, Supplement to Monthly Abstract of Statiśtics, November 1968.

Table III

Retail Turnover (Sea sonally Corrected)

Quarter

Ended

March

1962

1963

1964

1965

1966

1967

1968

1969
Total Turnover - $\$ \mathrm{mn}$.

Current Constant

\$'s $1957 / 58$ \$'s

299.4

317.2

330.2

359.2

383.0

391.8

396.3

417.2

$$
\begin{aligned}
& 278.2 \\
& 292.4 \\
& 298.2 \\
& 312.8 \\
& 327.4 \\
& 321.8 \\
& 313.5 \\
& 312.5
\end{aligned}
$$

\begin{tabular}{|c|c|}
\hline Current & Constant \\
\hline \$'s & $1957 / 58$ \$'s \\
\hline
\end{tabular}

121.3

112.7

125.8

116.0

$128.3 \quad 115.8$

$136.9 \quad 119.3$

$143.4 \quad 122.6$

$144.0 \quad 118.4$

$144.1 \quad 114.0$

$150.1 \quad 112.5$

Source: Retail Trade, supplement to Monthly Abstract of Statistics, May 1969.

Gross Domestic Product in constant prices fell in $1967 / 68$ and the volume of goods and services available fell for the first time since $195 \% / 59$. Total retail turnover in 
5.

constant prices has fallen for th ee successive March Quarters, and this year was back to the level of 1965. On a per head basis, retail turnover in constant prices in the March Quarter of this year was back to the level of 1962 .

By the end of 1967 it was obvious that external balance was being restored, but the internal stagnation was also becoming apparent. It was in these circumstances, that the National Development Conference was conceived, with the aim of mobilizing the country's resources to achieve a higher rate of economic growth per head whilst maintaining a reasonable external balance under conditions of lower export prices than had been forseen at the beginning of the decade.

The convening of the Conference was announced by the Prime Minister on February 6th 1968, and the formal objectives were laid down as follows:-

"To outline a programme and set targets for national development which over the next decade will give the necessary guidance and stimulus and provide the fullest opportunities and facilities for all sections of the community to develop and direct their resources, skills, 'know-how' and productive effort into those channels which can best promote economic growth and social development. In these ways to achieve a rate of economic progress which will ensure adequate employment opportunities for a growing population, maintain high levels of social welfare and promote a rising standard of living."

Committees were established to deal with various sectors (Manufacturing, Forestry etc.) or special fields (Labour, Education, Training and Research, etc.), with a Targets Committee co-ordinating the work of the other Committees, 
6.

and a Steering Committee handling the day to day management of the Conference.

The first plenary session of the Conference was scheduled for August 1968, at which time the Targets Committee was to present preliminary estimates of growth for the following 5 and 10 year periods based on the continuation of existing policies, together with an alternative set of projections showing what could be achieved given the appropriate changes in policies and attitudes.

Following the lst plenary session, committees were to consider the place of their sector or special field of interest in the overall objectives adopted, and make recommendations to the 2nd plenary session in May 1969 on measures required to stimulate the extra production and the shift in the allocation of resources necessary to achieve the targets.

One of the most significant points to note from this is the timing - a mere 15 months from the announcement that the Conference was to be convened, to the holding of the final plenary session. This obviously placed a severe limit on the scope and depth of the background research which could be carried out for the Conference, but there may be compensating benefits. The Vernon Report in Australia had its origins in a set of rather similar economic circumstances, but the period between the initial announcement of the setting up of the Committee of Economic Enquiry and the public release of its report was nearly three years. Professor Arndt has suggested that it was the improvement in the economic climate between the setting up of the Committee and the presentation of its Report which enabled an unconvinced Government to reject its recommendations. ${ }^{1}$ The 15 months time lapse in the New Zealand exercise has seen little fundamental change in 1. H.W. Arndt, A Small Rich Industrial Country. Studieg in Australian Development, Aid \& Trade, Cheshire, Melbourne, 1968 , p. 114. 
the country's overall economic situation and the Government has appeared receptive to most of the Conference proposals, some of which were hammered out in public at the plenary sessions. It is hoped that the research deficiencies will be made good by the permanent bodies which have been set up to continue the work of the Conference. The adverse reaction of the Treasury, to which Professor Arndt atiributes part of the Australian Government's attitude to the Vernon Report, was also avoided in New Zealand as the Treasury largely sponsored the Development Conference and the permanent machinery is to be set up under its wing.

Frorn the beginning, speed was obviously the essence of the contract, and with the responsibiity of presenting a set of projections to the 1 st plenary session of the Conference in August 1968, the Targets Committee was anxious to take advantage of research already completed. In February 1968, at the Agricultural Economics Research Unit at Iincoln College, we had got to the stage of making the first runs with an interindustry projection model of the New Zealand economy, and we were then invited to assist the Targets Committee in making internally consistent sectoral projections of the economy.

In the next section the sectoral model will be briefly outlined, and we shall then examine the ways in which it was modified in the light of the information coming forward from the sector committees. 
II. THE SECTORAL PROJECTION MODEL

The general role of the interindustry model was the provision of sectoral projections of the economy in the two. target years of $1972 / 73$ and 1978/79, which would result from a selected growth rate in consumption over the planning period, and in which the volume of output, investment etc. was at the level required to maintain this growth rate in subsequent years.

In particular, the model was programmed to estimate for each of the target years:-

(i) The level of gross investment required in each sector;

(ii) The level of current and capital imports required by each sector, which adeed to imports of finished goods for consumption gave total import requirements;

(iii) The level of exports required from each sector to ensure balance of payments equilibrium;

(iv) The level of gross output in each sector after allowing for all current and capital interindustry demands implied by (i)-(iii) above.

The model is based upon an estimate of the interindustry ${ }^{1}$ structure of the New Zealand economy in $1964 / 65^{2}$ representing an updating of the Official Government Statistician s 110 Sector Table for $1959 / 60$. Initially the interindustry

1 For non economists reading this paper we have, in an appendix to this paper given a very brief description of the nature and assumptions of interindustry or input-output tables and analysis.

2 See B.J. Ross \& B.P. Philpott, Interindustry Structure of the New Zealand Economy 1961-65 Agricultural Economics Research Unit Research Report No. 49, 1968. 
coefficienti ased for projections were those of 1964/65, but as work proceeded some of these were modified as will be explained later.

The structure of the New Zealand economy as revealed by our $1964 / 65$ table is shown in condensed form in Table 1 which gives by sectors, the main components of final demand, total output, imports, investment and labour force.

The purpose of our model is to calculate what the components of these columns must be in each of the target years if the desired increase in household and government consumption is to be achieved.

As programmed for the computer, the model proceeds by a series of iterative steps, and the solution process is most easily described by tracing these through stage by stage.

(1) Increase Consumption

The first step is the replacement of the consumption column of Final Demand in the base year, with new figures of sales by each sector to private and government consumption, which in the aggregate sum to the desired total for the target year. The spportionment between sectors was based on past trends in consumption together with projections of government spending provided by the Treasury. The insertion of the higher figures for consumption raises the level of final demand for the products of each sector, and hence increases the level of gross output required from each sector in the target year, as calculated by the normal input-output solution method. The new total outputs reflect the effects of higher consumption levels, but allowance has still to be made for the additional exports needed to pay for 
TABLE IV

NEW ZEALAND ECONOMY 1964/65

$\$ \mathrm{mn}$.

1964/65 Prices

\begin{tabular}{|c|c|c|c|c|c|c|}
\hline \multicolumn{3}{|c|}{ FINAL DEMAND } & \multirow[b]{2}{*}{$\begin{array}{l}\text { Total } \\
\text { Output } \\
\text { (incl. } \\
\text { Intermediate } \\
\text { sales) }\end{array}$} & \multirow[b]{2}{*}{ Imports } & \multirow[b]{2}{*}{ Investment } & \multirow[b]{2}{*}{$\begin{array}{l}\text { Laboux } \\
\text { Force } \\
1000\end{array}$} \\
\hline $\begin{array}{l}\text { Hous hold \& } \\
\text { Govt. } \\
\text { Consumption }\end{array}$ & Exports & $\begin{array}{l}\text { Capital } \\
\text { Formation } \\
\text { (incl. } \\
\text { stocks) }\end{array}$ & & & & \\
\hline 64 & 227 & 22 & 1037 & 38 & 103 & 119 \\
\hline 4 & 3 & 0 & 42 & 1 & 5 & 6 \\
\hline 7 & 20 & 8 & 252 & 16 & 10 & 24 \\
\hline 5 & 5 & 0 & 11 & 1 & 1 & 4 \\
\hline 7 & 0 & $\dot{0}$ & 45 & 4 & 3 & 5 \\
\hline 164 & 426 & 29 & 691 & 13 & 24 & 29 \\
\hline 690 & 25 & 195 & 1550 & 301 & 103 & 204 \\
\hline 44 & 0 & 518 & 717 & 33 & 40 & 86 \\
\hline 53 & 1 & 0 & 177 & 5 & 95 & 14 \\
\hline 116 & 69 & 25 & 528 & 28 & 90 & 93 \\
\hline 483 & 34 & 79 & 874 & 18 & 63 & 145 \\
\hline 64 & 8 & 0 & 157 & 4 & 16 & 27 \\
\hline 235 & 10 & 21 & 433 & 23 & 30 & \\
\hline 22 & & & 22 & & & 211 \\
\hline 241 & & & 241 & & 113 & \\
\hline 257 & 4 & 1 & 331 & 2 & 234 & Inc. in Banking \\
\hline 15 & 0 & & & & & \\
\hline 207 & 5 & & & 212 & & \\
\hline & & 120 & & 120 & & \\
\hline 49 & 1 & 5 & & & & \\
\hline 2725 & 838 & 1023 & & 816 & 929 & 968 \\
\hline
\end{tabular}

Building \& Constr

Public Utilities

10. Transport \& Comm.

11. Distribution

12. Banking \& Ins.

13. Services

14. Services to Households

15. Services to Govt.

16. Ownership of Property

Other Value Added

Imports-Consumption

Imports-Capital

Indirect $\mathrm{Tax}$

2725

838

1023

816 
11.

increased imports, and the increase required in the economy's capital stock.

\section{Imports and Exports}

Imports required by the new levels of gross outputs are calculated using import: output coefficients (based on those for 1964/65 but adjusted to allow for import substitution). Equilibrium in the target year's balance of payments is achieved by setting total exports equal to required imports of all kinds (current and capital inputs to sectors plus direct consumption imports). In the first version of the model, each sector was assumed to provide the same proportion of total exports in the target year as in 1964/65.

\section{Investment}

To provide the higher level of output as in (I), the capital stock of the economy must be increased. The supply of capital goods to each sector in the target year is that amount which, having been sustained annually from the base year, would be sufficient to raise the sector's capital stock to the level required in the final year, after allowing for replacements. The extra capital required by each sector is calculated using incremental net capital output ratios, based on the recorded investment and output changes over the period $1959 / 60$ to $1964 / 65$, applied to the required changes in output. The addition of an allowance for depreciation provides an estimate of the gross investment required in each sector. The pattern of production of the required capital goods in the target year is estimated by using an interindustry capital matrix, showing by sectors the source of 
capital invested in each sector. ${ }^{1}$

\section{Further Iterations to Equilibrium.}

The new estimates of exports and capital goods production are now inserted in the place of the corresponding columns in the Final. Demand estimate used for the first iteration described in section (I) above. The new, higher, Final Demand leads as before to increases in output and hence to demands for still more exports and investment. These demands are met by the processes described in sections (II) and (III), and the whole procedure is repeated until equilibrium is established (usually after about thixty iterations).

This equilibrium represents, for a given level of total consumption expenditure, the projected situation in the target year, with all interindustry relationships satisfied.

During the period in which we were working with the Targets Committee, several modifications were incorporated into the model. For example, although the model was run in constant 1964/65 prices, allowance was made for the adverse changes expected in the terms of trade between the base year and the target years of $1972 / 73$ and $1978 / 79$. The balance between exports and imports was thus carried out in the current prices of the target year, The form of the balance was also altered to take account of the

1 See T.W. Francis, Sectoral Capital Formation in New Zealand 1958-65, Agricultural Economics Research Unit Research Report No. 52, 1968. 
13.

private capital inflow expected; exports were thus set equal to imports less the capital inflow.

As the work of the various sector committees of the Conference proceeded, estimates became available of the expected volume and value of exports available from some of the more important sectors. These were incorporated into the model, and the sectors for which exports were not 'fixed' in this way then had to provide exports equal, in current values, to imports, less capital inflow, less exports already determined outside the model.

A further modification was made to allow for the continuation of the development of import replacement industries. This was done by lowering all import coefficients by a given percentage, and making a corresponding adjustment to the coefficient representing purchases from the Manufacturing sector. In other words, we made the rather simple assumption that import substitution consists of the replacement of imported goods by locally manufactured commodities. We thus ignored the possibility of replacenscat in the fields covered by invisible payments, but any distortion this causes is likely to be small.

The last major modification to the framework of the original simple model was introduced to cater for the large amount of investment which cannot be handied by simple capital: output ratios. Initially this was confined to government investment in buildings, roads and so on, but it was later extended to other fields as well.

Further molifications were made to adapt the model more closely to the view of the future as seen by the sector committees, but these will be dealt with in the next section. 
III. INITIAL TARGETS

The first task of the Targets Committee was obviously the selection of a target rate of growth, and this was done by examining the feasibility of various rates of increase in Cross National Product, using two different models. The first was a simple macro-model prepared by the New Zealand Institute of Economic Research, using the broad aggregates of total consumption, investment, exports, imports and so on. Starting from forecasts of the maximum increased volume of exports available over the period, and the expected terms of trade, (assumed to decline by 5 per cent between $1967 / 68$ and the target years, as a result of a 5 per cent ise in export prices and a 10 per cent increase in import prices) sets of projected national income aggregates were produced for $1972 / 73$ and $1978 / 79$ corresponding to different rates of increase in consumption expenditure (both private and government). The projected levels of investment and imports, derived from historical capital : output ratios and the funds available for the purchase of imports, were tested for feasibility against historical ratios of investment: G.N.P., imports G. N. F. and historical import propensities.

Different total consumption possibilities for the target years were also examined with our own sectoral model. The overall feasibility of the various projections was tested by comparing the required investment: C. N.P. ratios with the historical series, the required exports with the estimated total, as used in the macro-model, and the required labour force with the projected supply of labour in the target years. The total investment requirements as estimated by the two methods were also compared. 
15.

From all the initial projections, consumption targets were eventually adopted which gave the greatest increases in consumption per head over the two planning periods consistent with the restraints imposed by the investment requirements, limited labour force and availability of imports. The se consumption targets, and the rates of growth in Gross National Product which they implied, formed the basis of recommendations in the first report of the Targets Committee.

\section{SECTOR COMMITTEE CONSULTATIONS}

The first plenary session of the National Development Conference was held in August 1968. The guidelines for the overall growth of the economy recommended by the Targets Committee were adopted at this session, but the individual sectoral projections which had been prepared were not presented. These were circulated to the sector committees after the plenary session, and the preliminary report of the Targets Committee cont 'ned the following comments:-

"The projections are in general based on the production and consumption patterns of the last few years and form a consistent picture of the interrelationships between the various sectors. This does not imply that they are in any sense pre-ordained. A very important aspect of the work of the National Development Conference is the analysis, sector by sector, by the experts involved in the sector committees of these broadly based forecasts to see whether they are realistic or not. The Targets Committee proposes to find out from the other committees: 
16.

(a) Sector committet siews on the realism and feasibility of figures in the Iincoln model.

(b) Independent estimates by the sector committees of capital expenditure, labour resources required, output, and direct imports for the target years."

Once the sector committees had had time to prepare their own estimates and to examine those of the Targets Committee, a precess of reconciliation was carried out through a series of metings between representatives of the sector committees and a Technical Sub-committee of the Targets Committee.

Obviously it is not possible to describe all the discussions in detail, but as the dialogue carried on with the representatives of the Manufacturing Committee was probably the most important it deserves special atiention. The procedure was basically similar in all cases, and a description of the negotiations with the Manufacturing sector will also illustrate the general approach used.

The first estimates put forward by the Manufacturing Sector Committee postulated a $6.0 \%$ per annum increase in the Sector's output between $1965 / 66$ and $1972 / 73$, and $6.8 \%$ per annum from 1972/73 to 1978/79. 1965/66 had been chosen as a base year because it was the latest yea $r$ for which full manufacturing statistics were avail able, but with the reduction in output which had occurred in the offical base year of $1967 / 68$, the use of $1965 / 66$ had the effect of distorting the growth rate. From our estimate of manufacturing output in 1967/68, the average growth of $6.0 \%$ from $1965 / 66$ represented a rate of more than $7.5 \%$ per annum between $1965 / 66$ and $1972 / 73$. In view of the fall in the level of investment which had accompanied 
the reduction in output, we felt that $7 \frac{1}{2} \%$ was too high, and said so. On the other hand, we had felt all along that our own first estimate of about $4 \%$ was too low in relation to the rates of growth achieved in the past decade, but had not had time to investigate why.

The first discussions with the Sector Committee revealed differences in our as sumptions about the rate at which sales to consumers would increase, and agreement on this point alone went some way towards reducing the gap between our estimates of output growth.

Shortly after the August plenary session of the Conference we finished a revised estimate of the 1964/65 interindustry structure of the economy, and the use of the revised coefficients produced a slight increase in our projected output for the Manufacturing sector.

In our original assumptions about import substitution we had taken it for granted that imports of capital goods were unlikely to be replaced by local manufacturers as quickly as imports of consumer goods and items used as current inputs by the various sectors. Import substitution of capital goods bad therefore been set at half the rate assumed for current inputs. The Sector Committee, however, presented evidence of rapid expansion of capital goods production in New Zealand, and the also pointed out the degree to which substitution possibilities for consumer imports and current inputs had already been exhausted. In the light of this, we raised the rate of import substitution of capital goods to the same level as that assumed for all other imports. 
18.

It was at about this stage in the reconciliation procedure that the New Zealand Institute of Economic Research, who had also been working on interindustry models of the economy, pointed out that the increase in the intermediate sales by the Manufacturing Sector since 1954/55 had been very much greater than the increase in sales to any category of final demand. This implied a significant change over the period in the coefficients representing purchases by sectors from Manufacturing. Investigation of our own time series (something we had not previously had time to do) confirmed that an increase had taken place in the relevant coefficients, and in addition it showed that the increase was considerably greater than the decrease in the import coefficients. In other words, intermediate sales by the Manufacturing Sector have been increasing at a faster rate than can be explained in terms of import subsitution alone. The reasons for these changes are still in doubt. Although they may stem from a trend towards manufacturing in greater depth, it is possible that they simply result from the fact that items produced locally behind a protective barrier often cost more than the imports which they replace. Measurement of changes in the real volume of production is difficult when the range of goods is constantly being extended, and this is a problem which we have not yet solved to our own satisfaction. For the purposes of the projection work, however, we incorporated an additional increase in the Manufacturing intermediate sale coefficients. If this produces an upward bias in the output estimates for the Manufacturing Sector, at least it will be a continuation of a bias already present in the historical series.

All these changes had the effect of increasing the rate of growth as estimated by the model, and the estimates by the Sector Committee were being reduced at the same time. 
We were successful in persuading the Committee that the growth experienced between 1963 and 1966 had only been possible under conditions of substantial improvements in the terms of trade and unacceptable balance of payments deficits.

The net result of the negotiations was that the estimates from the interindustry model were raised to 6.0 per cent per annum while those of the Sector Committee were reduced to 6. 4 , per cent. The remaining difference was thought to be acceptable in view of the differences in the definitions of the Manufacturing Sector, the wider Interindustry definition including such things as railway workshops, naval dockyards, and one-man establishments, all of which could be expected to have lower growth rates than the sector as a whole.

Negotiations with other sectors produced similar reconciliations. Our estimates of the value of houses to be built, for example, were well below those of the Building Committee, and investigation revealed that we had not made sufficient allowance for the number of housing units lost in city centres each year. Conversion of old houses to small offices or factories, and demolition to make way for new buildings, is quite a common practice, and about 20 per cent of each year's output of houses is required to replace the units lost in this way. Improvements in the quality of hous es to be built were also incorporated. The additional housing investment required was incorporated by inserting an exogenous value of investment, which in the model was added to the housing investment generated by consumer demand.

A similar procedure was followed with investment in the Public Utilities Sector. The Electricity Department plans for capital expenditure were incorporated into the model to take account of the variations which can occur from year to year. 
20.

This was the only investment estimate in the final solution which was not calculated under the assumption that net investment between the base and target years would take place in equal annual amounts.

The changes incorporated in the framework of the model after August, involving import substitution of capital goods, adjustments to the Manufacturing Sector's intermediate sales coefficients and exogenous additions to investment in housing and Public Utilities, all improved the model by bringing the projected structure of the economy closer to that expected by the technical experts in each sector, whilst the benefits of being able to estimate interactions between industries were preserved. A few minor data changes were also made after Aug.ast, involving the substitution of revised estimates of exports and government investment for those used in the August projections.

The final projections for $1972 / 73$ and $1978 / 79$ incorporating all the amendments, are presented in Tables $\mathrm{V}$ and $\mathrm{VI}$. 
TABLE: $\mathrm{V}$

NEW ZEALAND ECONOMY 1972/73

$\$ m n$.

1964/65 Prices
FINAL DEMAND

\begin{tabular}{|c|c|c|c|c|c|c|}
\hline $\begin{array}{l}\text { Household } \\
\text { \$ Govt. } \\
\text { Consumption }\end{array}$ & Exports & $\begin{array}{c}\text { Capital } \\
\text { Formation } \\
\text { (incl. } \\
\text { stocks) }\end{array}$ & $\begin{array}{c}\text { Total } \\
\text { Output } \\
\text { (incl. } \\
\text { Intermediate } \\
\text { sales) }\end{array}$ & Imports & Investment & $\begin{array}{l}\text { Labour } \\
\text { Force } \\
\text { '000 }\end{array}$ \\
\hline
\end{tabular}

CURRENT PRICES

Exports Imports

rimports

\begin{tabular}{|c|c|c|c|c|c|c|c|c|c|}
\hline 1. Farming & 74 & 351 & 41 & 1469 & 51 & 160 & 128 & 276 & 60 \\
\hline 2. Forestry & 6 & 4 & 1 & 60 & 2 & 9 & 9 & 11 & 2 \\
\hline 3. Forest Processing & .10 & 41 & 10 & 355 & 21 & 18 & 26 & 50 & 24 \\
\hline 4. Hunting \& Fishing & 6 & 9 & 0 & I7 & 2 & 3 & 6 & 12 & 2 \\
\hline 5. Mining & 11 & 0 & 0 & 62 & 5 & 9 & 6 & 0 & 5 \\
\hline 6. Primary Prod. Proces. & 189 & 590 & 29 & 904 & 16 & 27 & 38 & 581 & 18 \\
\hline 7. Other Manufacturing & 898 & 80 & 254 & 2184 & 404 & 85 & 245 & 91 & 470 \\
\hline 8. Building \& Constr. & 67 & & 670 & 936 & 41 & 88 & 100 & 0 & 48 \\
\hline 9. Public Utilities & 66 & 2 & 0 & 228 & 6 & 98 & 13 & 2 & 6 \\
\hline 10. Transport \& Comm. & 156 & 124 & 33 & 748 & 38 & 137 & 106 & 136 & 44 \\
\hline 1. Distribution & 566 & 53 & 119 & 1120 & 22 & 68 & 156 & 58 & 25 \\
\hline 12. Banking \& Ins. & 79 & 13 & 1 & 203 & 4 & 21 & 2.7 & 14 & 5 \\
\hline 13. Services & 293 & 16 & 32 & 60 & 28 & 19 & & 18 & 33 \\
\hline 14. Services to Households & 27 & & & 27 & & & 259 & & \\
\hline 15. Services to Govt. & 315 & & & 315 & & 228 & & & \\
\hline 16. Ownership of Property & 355 & 6 & & 451 & 2 & 265 & in Banking & 7 & 2 \\
\hline Other Value Added & 18 & & & & & & & & \\
\hline Imports-Cons. & 218 & & & & 218 & & & & 253 \\
\hline Imports - Capital & & & 176 & & 176 & & & & 205 \\
\hline Indirect Tax & 59 & 2 & & & & & & 3 & \\
\hline TOTAL & 3414 & 1291 & 1364 & & 1033 & 1234 & 1117 & 1258 & 1204 \\
\hline
\end{tabular}

Balance between exports and imports in current prices is achieved after allowance is made for net capital inflow, net factor payments abroad, and transfers. 
TABLE VI

NEW ZEALAND FCONOMY 1978/79

$\$ \mathrm{mn}$.

1965/65 Prices

\section{FINAL DEMAND \\ Exports}

Househol

Govt.

Consumption
Formation

(incl.

Total

Output

Imports Investment

(incl.

termediate

sales)

1. Farming 88

2. Forestry

3. Forestry Processing

4. Hunting \& Fishing

5. Mining

6. Primary Prod. Proces.

7. Other Manufacturing

8. Building \& Constr.

9. Public Utilities

10. Transport \& Comm.

11. Distribution

12. Banking \& Ins.

13. Services

14. Services to Households

15. Services to Govt.

16. Ownership of Property

Other Value Added

Imports-Cons.

Imports-Capital

Indirect Tax

TOTAL

88
8
13
8

8
15

15
225
1237

87
88
202

202

705
105

388

36

421

423

24

250

76

4398

429

2
65

16
1

712

179

1
3

3
191

82

20

25

1784
77
485
28
83
1087
3054
1265
300
1023
1448
268
744
36
421
549

62
2

2
28
3

3
6

19

565

$55 \quad 176$

7
52

38

32
25

$52 \quad 229 \quad 109$

$\begin{array}{rll}28 & 104 & 170\end{array}$

$\left.\begin{array}{l}25 \\ 286\end{array}\right\} 326$

Forre

1000

RENT PRICES

Exports Imports

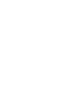

Balance between exports and imports in current prices is achieved after allowance is made for net capital

inflow, net factor payments abroad, and transfers. 
The final projections have considerable significance in themselves, but the major interest lies in the degree to which the results obyained from the interindustry model finally measured up to the estimates from other sources such as the macro-model and individual sector committees.

Table VII sets out for the base year and the two target years, a comparison of the main aggregates as derived from national income statistics and the macro-model, with those from the sectoral model. The differences in the base year stem from the slightly wider coverage of some items by the sectoral model together with minor differences in definitions.

In general, the level of agreement in the projections is good. The consumption figures for the target years naturally bear the same relationship to each other as in the base year as they are exogenously determined, but the agreement between the estimates of imports and exports is very close indeed. The level of investment projected by the sectoral model is 18 per cent above the macro-estimate in 1978/79, compared with 13 per cent in 1964/65, and while it is not big enough to be a cause of major concern, this is the aggregate where the discrepancy between the two sets of projections is largest. This difference in estimated investment expenditures is largely attributable to the higher level of replacement expenditure projected by the sectoral model, and we shall return to this subject later. On the whole, the degree of reconciliation achieved between these two sets of projections wa considered to be satisfactory. 
(1964/65 Prices)

\begin{tabular}{|c|c|c|c|c|c|c|c|c|c|}
\hline & \multicolumn{3}{|c|}{$1964 / 65$} & \multicolumn{3}{|c|}{$1972 / 73$} & \multicolumn{3}{|c|}{$1978 / 79$} \\
\hline & $\begin{array}{l}\text { National } \\
\text { Income }\end{array}$ & $\begin{array}{l}\text { Inter - } \\
\text { Industry }\end{array}$ & $\begin{array}{l}\text { Ratio } \\
\text { Inter- } \\
\text { Industry } \\
\text { to } \\
\text { National } \\
\text { Income }\end{array}$ & $\begin{array}{l}\text { National } \\
\text { Income }\end{array}$ & $\begin{array}{l}\text { Inter- } \\
\text { Industry } \\
\$ \mathrm{mn} \text {. }\end{array}$ & $\begin{array}{l}\text { Ratio } \\
\text { Inter- } \\
\text { Industry } \\
\text { to } \\
\text { National } \\
\text { Income }\end{array}$ & $\begin{array}{l}\text { National } \\
\text { Income }\end{array}$ & $\begin{array}{l}\text { Inter - } \\
\text { Industry }\end{array}$ & $\begin{array}{l}\text { Ratio } \\
\text { Inter- } \\
\text { Industry } \\
\text { to } \\
\text { National } \\
\text { Income }\end{array}$ \\
\hline Aggregates - & & & & & & & & & \\
\hline $\begin{array}{l}\text { Consumption } \\
\text { Investment (incl }\end{array}$ & 2592 & 2725 & 1.05 & 3252 & 3414 & 1.05 & 4211 & 4398 & 1.04 \\
\hline stock) & 909 & 1023 & 1.13 & 1226 & 1364 & 1.11 & 1594 & 1887 & 1.18 \\
\hline $\begin{array}{l}\text { Exports } \\
\text { Imports (incl net }\end{array}$ & 838 & 838 & 1.00 & 1297 & 1291 & 1.00 & 1720 & 1736 & 1.01 \\
\hline factor payments) & 852 & 880 & 1.03 & 1124 & 1122 & 1.00 & 1492 & 1501 & 1.01 \\
\hline Gross National Product & 3487 & 3706 & 1.06 & 4448 & 4748 & 1.07 & 5779 & 6264 & 1.08 \\
\hline $\begin{array}{l}\text { Growth Rates - } \\
\text { Consumption } \\
\text { Investment } \\
\text { Fxports } \\
\text { Gross National Product }\end{array}$ & & & & $\begin{array}{l}\text { Pex cer } \\
2.9 \\
3.8 \\
5.6 \\
3.1\end{array}$ & $\begin{array}{l}\text { per Ann } \\
2.9 \\
3.7 \\
5.6 \\
3.1\end{array}$ & $u m$ & $\begin{array}{l}3.5 \\
4.1 \\
5.3 \\
3.7\end{array}$ & $\begin{array}{l}3.5 \\
4.1 \\
5.3 \\
3.8\end{array}$ & \\
\hline $\begin{array}{l}\text { Ratios - } \\
\text { Investment/GNP } \\
\text { Imports/GNP }\end{array}$ & $\begin{array}{l}26.1 \\
24.4\end{array}$ & $\begin{array}{l}27.6 \\
23.7\end{array}$ & $\begin{array}{r}1.06 \\
.97\end{array}$ & $\begin{array}{l}27.6^{\mathrm{Pe}} \\
25.3\end{array}$ & $\begin{array}{l}r \text { cent } \\
28.7 \\
23.6\end{array}$ & $\begin{array}{r}1.04 \\
.93\end{array}$ & $\begin{array}{l}27.6 \\
25.8\end{array}$ & $\begin{array}{l}30.1 \\
24.0\end{array}$ & $\begin{array}{r}1.09 \\
.93\end{array}$ \\
\hline
\end{tabular}


One of the objectives set for the projections was that full employment should be achieved in the target years. But experience has shown that, through such things as changes in female participation rates and levels and direction of migration, the size of the labour force tends to vary in response to changes in the labour market. Equating the demand for labour with the expected supply, therefore requires knowlerio as to the way in which demand affects the supply. Unfortunately our understanding of this whole field in New Zealand is still rather limited, and the projections of the available labour force prepared by the Manpower Planning Unit of the Department of Labour are based solely on expected population growth and historical participation rates.

Sectoral labour force requirements were calculated for the target years by dividing the total. output of each sector by the estimate of the output per worker in that sector in the appropriate year. The labour productivity figures were based on the observed trends between $1959 / 60$ and 1964/65, with an allowance made for the lower rate of investment experienced over the last couple of years.

Our estimates of total labour requirements come to within one per cent of the supply estimates, but the level of agreement with the requirement estimates made by individual sector committees is not quite as good. Labour requirements we re not covered in the consultations with the sector committees, and future discussions on such topics as the best historical period from which to derive trends in productivity, or estimates of output per man in major projects already planned, will probably resolve most of the differences. The sum of the sector committee estimates exceeds the projected supply of labour by about three 
per cent in 1972/73 and five per cent in 1978/79, but in view of the flexibility of the labour force, and the lack of any attempt to reconcile the estimates of supply and demand, these projections are thought to be consistent with the aim of full employment equilibrium in the labour market.

The investment requirements projected by the sectoral model proved to be a little above the estimates obtained in a survey carried out by the Treasury. For almost every sector the model set the requirements slightly above the estimates obtained from sector committees, Government Departments and independent estimates. The survey totals agree closely with the macro-model aggregates, but the authors of the survey concede that, especially for $1978 / 79$, their projections are likely to understate the actual expenditure, as they believe there is a tendency among respondents to take insufficient account of the requirements of projects not yet planned.

Direct comparisons of the projected levels of employment and investment obtained by different methods have not been possible for some sectors because of differences in definitions. The interindustry model embraces the whole economy, but some sector committees did not cover the full range of activities which have been attributed to their sectors in the model. Where possible, growth rates of labour and investment requirements were compared in such cases, but in at least some instances the activities not covered by the committees are likely to experience slower growth than the rest of the sector.

While we would hope that future work will eliminate the definitional differences and reduce the present discrepancies in the projections, the general level of agreement between the existing interindustry and other estimates of sectoral and 
aggregate investment and labour requirements were considered most satisfactory in view of the research time available.

VI. IMPROVEMENTS TO THE MODEL AND SOME CONCLUSIONS

Before concluding it is worth briefly discussing more explicitly some of the imperfections in the present sectoral model, and the improvements we hope will come from further work. In many cases, work is already proceeding on these modifications, but the deadlines set made it impossible to incorporate them in the projections for the National Development Conference.

The following in a short list of deficiencies and improvements.

(1) Data problems quickly assume major proportions when attempts are made to gather the amount of information required to up-date interindustry tables. Fortunately, the background work for the Development Conference also brought home to many other people the lack of statistical material available in some fields, and one of the first positive actions following the Conference has been the setting up of a technical committee to examine the statistical needs of the country if planning is to be improved.

The area where data deficiencies, coupled with certain conceptual difficulties, have probably had their greatest effect on the sectoral model is in the field of investment expenditures. Because we assume increases in output are linked 
to increases in the stock of capital, capital:output ratios should be based on net, rather than gross investment. This is particularly important if rates of investment in the projection period are likely to differ from those of the historical period from which the ratios are derived, and this is a possibility for which we wanted to make an allowance. The use of net capital:output ratios, however, requires the estimation of both past and projected replacement expenditures. The ratios used in the model are derived from gross investment minus recorded depreciation, and it seems likely that these estimates could be considerably improved. The depreciation rates used for estimating future replacement expenditure have produced estimates which are high in relation to past experience, and further work is needed in this area.

(2) Devaluation in late 1967 and the changes in economic structure which it is designed to produce, but which have not fully worked themselves out, had to be largely ignored, or at best, arbitrary allowance made. With $1967 / 68$ being used as the official base year for the Conference, the base year prices were combinations of pre-and post-devaluation situations.

(3) Fixed Input-Output Coefficients. Apart from the changes to the coefficients for imports and interindustry sales by the Manufacturing Sector, which were described earlier, the coefficients used in the projections have been those estimated for 1964/65. Preliminary work on changes between 1960 and 1965 indicates a surprising degree of stability in the coefficients but, especially following devaluation, some changes should be allowed for by the target years. 
As with all simple input-output models the chosen coefficients are fixed regardless of the level of output, but time series production functions are being used to examine the historical capital-labour-output relationships, which may make it possible to incorporate changes in primary input coefficients. This could be especially useful in projecting labour force requirements.

(4) Disaggregation of Sectors. The use of a

highly disaggregated model is hardly justified for the level of planning being pursued at the moment, but it is hoped to extend the model to about twenty sectors. Disaggregation of the Farming Sector is proceeding to take account of the varying input mixe in sub-sectors with vastly different marketing prospects for their products. The Manufacturing Sector should also be divided at least into sub-sectors which do, or do not, require high levels of protection from competitive imports. There is still a lot of work to be done on real rates of protection in New Zealand before such a division can be made, but with the large official table for $1959 / 60$ as a guide, the actual disaggregation of this sector presents few problems.

(5) Optimisation. Although the projettions derived from the present model represent feasible ways in which the consumption targets could be reached, the structure of the economy depicted in the target years is not necessarily the best one. It is possible that some other structure would allow the consumption demands to be satisfied in a manner which used fewer resources, and in this event the consumption targets could be raised. Work has already commenced on a linear programming model which should 
30 .

allow us to draw some definite conclusions about the optimal structure of the economy, but, as we have explained elsewhere ${ }^{1}$ we think that the present projection for $1978 / 79$ is probably not too far from the optimum, given the restraints imposed by such things as overseas market prospects, and the limitations of our present data.

(6) Best Practice Coefficients. In addition to ensuring that we have achieved the best balance between sectors in the economy, it is also desirable that we should know the best way, in the future, for each sector's output to be produced. Rather than relying upon coefficients calculated from historical data, it may be possible to base estimates of the requirements of additional output from any sector on the current ideas of the best methods of production. In narrowly defined sectors such as Forest Processing, collaboration in this field with the Sector Committees could substantially improve the value of the projections as forecasts.

For the moment, however, the ways in which the mudel might be improved in the future are not as important as the modifications which have already been introduced. The need for some of the improvements only became obvious in the process of using the model for practical purposes and justifying the results to sector committees. Thus the consultation process provided a source of improvement which is usually denied to the academic. Within the framework of the new planning machinery now being set up in New Zealand, it is to be hoped that as thehasty research of the last eighteen

1. B.P. Philpott and B.J. Ross, "The Structure of the New Zealand Economy in 1979." New Zealand Economic Papers, for theoming. 
31.

months is supplemented by more exhaustive investigation, the use of the consultative process will continue to enhance the value of the projections as indications of the likely and desirable future shape of the economy. Apart from the fact that consultation is an integral part of indicative economic planning, the educative value to all concerned of being forced to see other points of view, and the sense of involvement gained by the business leaders whose decisions will make or break the plan, must in themselves have gone some way to ensuring the ultimate achievement of the targets laid down. 


\section{APPENDIX}

\section{The Input-Output Table}

A table is drawn up for a given year showing for each of the major sectors of the economy, the disposal of the sector's output and the sources of the inputs used. Since inputs are defined to include profits, the total value of a sector's output is always equal to the value of inputs used. By convention, the rows of the table show the disposal of output, while sources of inputs are listed in the columns. 
TABLE $A: 1$

Current Transactions Table 1964/65

\begin{tabular}{lcccccc}
\hline \$mn. & Primary & Secondary & Tertiary & $\begin{array}{c}\text { Total } \\
\text { Intermediate } \\
\text { Sales }\end{array}$ & $\begin{array}{c}\text { Final } \\
\text { Demand }\end{array}$ & $\begin{array}{c}\text { Total } \\
\text { Output }\end{array}$ \\
\hline $\begin{array}{l}\text { Primary } \\
\text { Secondary }\end{array}$ & 836.0 & 182.4 & 69.2 & 1087.6 & 990.6 & 2078.2 \\
Tertiary & 145.8 & 419.8 & 228.9 & 794.5 & 1472.7 & 2267.2 \\
\hline $\begin{array}{l}\text { Total } \\
\text { Intermediate }\end{array}$ & 208.9 & 331.8 & 501.3 & 1042.0 & 1720.8 & 2762.8 \\
$\begin{array}{l}\text { inputs } \\
\text { Total }\end{array}$ & 1190.7 & 934.0 & 799.4 & 2924.1 & 4184.1 & 7108.2 \\
$\begin{array}{l}\text { Frimary } \\
\text { Inputs }\end{array}$ & 887.5 & 1333.2 & 1963.4 & 4184.1 & 401.8 & 4585.9 \\
\hline \begin{tabular}{l} 
Total Inputs \\
\hline
\end{tabular} & 2078.2 & 2267.2 & 2762.8 & 7108.2 & 4585.9 & 11794.1 \\
\hline
\end{tabular}


Sales by a sector fall into two groups; intermediate sales to other sectors which will use the goods or services purchased as part of their inputs; or sales to final demand, in which the goods sold will not be used in the productive process in the year under study. Items in the final demand category comprise such things as sales to consumers, sales to other countries (exports) and sales of capital goods.

In Table $A_{1} 1$, the Primary Sector is shown as making total intermediate sales of $\$ 1088 \mathrm{mn}$., of which $\$ 182 \mathrm{mn}$. is sold to the Secondary Sector. The total sales to final demand by the Primary Sector come to $\$ 191 \mathrm{mn}$.

Inputs are also divided into two groups; intermediate purchases of goods bought from other sectors, and primary inputs which consist of goods not produced within the economy in the given year (payments for labour, imports, the use of capital and so on). The total intermediate inputs used by the Secondary Sector, according to Table A.:1 were $\$ 934 \mathrm{mn}$., of which $\$ 332 \mathrm{mn}$. were purchased from the Tertiary Sector. The value of primary inputs used by the Secondary Sector was $\$ 1333 \mathrm{mn}$., making a total of $\$ 2267 \mathrm{mn}$. for all inputs, and this is equal to the value of the Sector's output.

By dividing each input purchase by the total value of inputs (or output), it is possible to calculate for each sector the value of inputs required from each sector and each category of primary inputs, per dollar of total output. Assuming a linear relationship between inputs and output, it is then possible to calculate the level of each input purchase for any given level of total output. The matrix of input-output coefficients derived from Table $A: 1$ is given in Table $A: 2$. 
TABLE $A_{-2} 2$

Input-Output Coefficients 1964/65

\begin{tabular}{lccc}
\hline & Primary & Secondary & Tertiary \\
\hline Primary & .402271 & .080452 & .025047 \\
Secondary & .070157 & .185162 & .082851 \\
Tertiary & .100520 & .146348 & .181446 \\
\hline Primary Inputs & .427051 & .588038 & .710656 \\
\hline Totals & 1.000000 & 1.000000 & 1.000000 \\
\hline
\end{tabular}

The matrix of coefficients showing

intermediate purchases per dollar of total output is known as the technology matrix, and the inverse of the matrix obtained by subtracting the technology matrix from a unit matrix, times the column sector of total final demands, gives an estimate of the total outputs required from all sectors to satisfy the chosen final demands. The total outputs calculated in this way take full account of all the interdependencies between sectors.

The inverse matrix derived from Table $A ; 2$ is:-
1.70612
.18112
.07054
.17131
1.26815
.13360
.24014
.24897
1. 25421

If final demands of $\$ 1485.9 \mathrm{mn}$, $\$ 1472.7 \mathrm{mn}$, and $\$ 1720.8 \mathrm{mn}$. are postulated, (representing a fifty per cent increase in the final demand for the output of the Primary Sector compared with Table $\mathrm{A}: 1)$ then the new total outputs will be:- $\$ 2923.2 \mathrm{mn}$, $\$ 2352.1 \mathrm{mn}$. , and $\$ 2881.7 \mathrm{mn}$. 